\title{
KAMPUNG TUA NONGSA SEBAGAI TUJUAN WISATA BERBASIS KEARIFAN LOKAL BUDAYA MELAYU BATAM
}

\author{
Ambalegin*1, Tomi Arianto ${ }^{2}$, Zefri Azharman ${ }^{3}$ \\ ${ }^{1,2}$ Program Studi Sastra Inggris, Fakultas Ilmu Sosial dan Humaniora, Universitas Putera Batam \\ ${ }^{3}$ Program Studi Teknik Industri, Fakultas Teknik dan Komputer, Universitas Putera Batam \\ Universitas Putera Batam; Jalan Letjen R. Soeprapto Tembesi. Batam, 0778-7001000 \\ *E-mail: abhi140475@gmail.com
}

\begin{abstract}
Batam sebagai kota metropolitan, memiliki beberapa kampung tua yang masih memegang teguh kearifan lokal Melayu. Kampung tua Nongsa adalah salah satu kampung tua yang masih memegang teguh kearifan lokal Melayu. Komunitas Capung di Nongsa bertujuan mempromosikan kampung tua Nongsa sebagai destinasi pariwisata Pulau Batam kepada wisatawan mancanegara karena letak strategis Pulau Batam yang dekat dengan Singapura, Malaysia, ataupun Brunai Darussalam. Anggota komunitas Capung yang berasal dari masyarakat tempatan memiliki latar belakang pendidikan menengah sehingga tidak memiliki kemampuan yang baik berbahasa Inggris lisan maupun tulisan dan menjadi kendala mempromosikan kearifan lokal Melayu kepada dunia. Pembinaan pelatihan bahasa Inggris untuk mengasah kemampuan lisan dan tulisan anggota komunitas dan pelatihan pemanfaatan media sosial sebagai strategi manajemen promosi wisata kampung tua adalah solusi dalam memecahkan masalah tersebut. Metode pengabdian berupa wawancara, pemberian pretest, pelatihan percakapan dan menulis, dan praktik percakapan langsung (posttest). Hasil dari enam pertemuan adalah peserta mulai mampu mendeskripsikan tempat wisata di Nongsa dan budaya Melayu walaupun masih banyak kesalahan dan peserta dapat memanfaatkan media sosial untuk mempromosikan keindahan dan kearifan budaya Melayu berbahasa Inggris. Pelatihan ini diharapkan dapat mensukseskan rencana kegiatan komunitas capung 'Heritage Culture Of Kampung Tua Nongsa 2019 dan mempromosikan kearifan lokal Melayu kampung tua sebagai landmark Pulau Batam.
\end{abstract}

Kata Kunci_kampung tua, kearifan lokal, media sosial, Melayu, pariwisata

\section{PENDAHULUAN}

Batam adalah salah satu pulau yang terdapat di provinsi Kepulauan Riau. Letak strategis pulau Batam yang dekat dengan Singapura dan Malaysia menjadi keuntungan tersendiri bagi pulau ini yaitu banyaknya wisatawan asing yang datang dan berlibur. Di samping menikmati keindahan alam Pulau Batam, wisatawan dari Malayasia, Brunai Darussalam, dan Singapura berkunjung ke Pulau Batam untuk mengetahui budaya daerah setempat khususnya budaya Melayu dengan mengunjungi kampung tua yang ada di pulau Batam. Seperti hadirnya 175 wisawatan dari Korea Selatan [1]. Salah satu sajian pariwisata yang mereka kunjungi adalah Kampung Tua Batam yang memang menjadi tujuan utama. Youn, ketua rombongan menegaskan, Kampung Tua menjadi destinasi utama yang diperbincangkan para turis. Mereka senang dengan pennyajian kearifan lokal, menonjolkan unsur budaya yang memiliki ciri tersendiri di masing-masing daerah.

Sejarah mencatat bahwa pulau Batam dan pulau sekitarnya sudah dihuni manusia sejak 231 M [2]. Pesisir Kepulauan Batam dihuni oleh Suku Laut atau disebut juga Orang Selat. Sedangkan di daratan (hutan belantara) dihuni suku pedalaman seperti Suku Sakai dan Suku Jakun yang hidup dengan mencari minyak kayu, damar, dan rotan. Sedangkan pada 1790, penduduk asli bernama A'lama yang beristrikan orang Melayu, membuka wilayah yang kemudian bernama Kampong Setenga. Pada 1813 dibuka pula perkampungan bernama Patam yang didiami orang Melayu dari Pahang. Sementara itu, pada 1817 telah ditemui penduduk etnis China di kawasan Sei Panas. Etnis China juga banyak yang bermukim di kawasan lain di kepulauan Batam seperti Duriangkang, Mukakuning, dan Tanjunguncang, Waheng, dan sebagainya. 
Umumnya kampung yang pertama kali muncul berada di pesisir. Sehingga banyak kampung-kampung tua yang berada di sekitar pantai. Pemerintah berkomitmen menjaga kelestarian budaya sebagai upaya keseimbangan kearifan lokal yang telah ada sejak dulu di tengah kemajuan zaman dengan menetapkan kawasan kampung tua yang jumlahnya ada 33 kawasan di seluruh Batam sebagai wujud menjaga kearifan lokal [3]. Kearifan lokal biasanya tercermin dalam kebiasaan-kebiasaan hidup masyarakat yang telah berlangsung lama. Keberlangsungan kearifan lokal akan tercermin dalam nilai-nilai yang berlaku dalam kelompok masyarakat tertentu. Nilainilai itu menjadi pegangan kelompok masyarakat tertentu yang biasanya menjadi bagian hidup tak terpisahkan yang dapat diamati melalui sikap dan perilaku sehari-hari (Ridwan dikutip pada [4]).

Kampung tua yang potensial sebagai destinasi wisata disebutkan, seperti kampung tua Terih, Sambau, Nongsa, Tanjung Uma dan kampung tua Bagan. Selama ini kampung tua ini masih dikelola penduduk setempat dan belum menarik bagi wisman padahal potensinya sangat besar. "Kita ingin mendorong itu agar pemerintah pusat membantu yang merupakan bentuk komitmen pemerintah khususnya Pemko Batam," ujarnya Kepala Dinas Parawisata (Kadispar) Batam, Pebrialin, di Batam.

Pantai Nongsa Batam dan Kampung Tua Nongsa berada di kawasan Nongsa Batu Besar Pulau Batam. Nongsa adalah daerah di sebelah utara Pulau Batam. Di lepas pantai Nongsa terdapat pulau kecil yaitu Pulau Puteri yang merupakan salah satu pulau terluar Indonesia. Pulau Puteri ini memiliki cerita legenda, konon Pulau Puteri merupakan seekor ular raksasa yang terdampar lantaran kesiangan turun ke laut. Nongsa adalah kecamatan yang merupakan perkampungan penduduk paling awal di Pulau Batam. Sebagian besar perkampungan di Nongsa merupakan kampung tradisional. Oleh karenanya kawasan Nongsa dikenal sebagai Kampung Tua di Batam.

Di dalam "Berknoopte aantekening over het eiland Bintan 1833" (Ringkasan catatan tentang Pulau Bintan Tahun 1833) tertulis bahwa penulisnya menjelaskan Raja Isa atau Nong Isa berusia sekitar 50 tahun ketika itu, dan kampung kecil tempat ia bersemayam terletak di hulu sungai Nongsa di Pulau Batam. Selain dikenal sebagai tokoh yang membuka Nongsa, sebuah kampong atau negeri yang baru di Pulau Batam pada awal abad ke-19, selembar arsip yang ditemukan dalam koleksi Arsip Riouw yang tersimpan di Arsip Nasional Republik Indonesia (ANRI), disebutkan pula bahwa Raja Isa diberi "kuasa" memegang perintah atas Nongsa dan rantau sekitarnya di bawah pemerintahan Sultan Abdulrahman Syah yang bersemayam di Lingga dan Yang Dipertuan Muda Riau Raja Jakfar di Pulau Penyengat [5].

Dibandingkan daerah lain di Pulau Batam, Nongsa relatif belum terlalu masif dijamah pembangunan industri maupun pusat bisnis. Pemko Batam berharap partisipasi komunitas yang bergerak di bidang pariwista dan masyarakat bisa memanfaatkan kampung tua sebagai tempat wisata. Sehingga ke depan, keberadaan kampung tua sebagai destinasi parawisata semakin nyata. "Kita harus bersama-sama. Tidak bisa hanya pemerintah," harap Kepala Dinas Parawisata (Kadispar) Batam, Pebrialin di Batam. Dengan memberikan pelayanan terbaik, bukan tidak mungkin nantinya Pulau Batam akan menjadi destinasi wisata favorit yang akan dikunjungi wisatawan dari berbagai belahan dunia. Intensitas kunjungan wisatawan yang diharapkan tinggi menjadikan ekonomi Pulau Batam lebih baik. "Di samping meningkatan geliat perekonomian kampung tua, nantinya mereka dapat mengisi hotel-hotel di sini, berwisata di tempat-tempat indah di Pulau Batam" kata Kepala Dinas Parawisata (Kadispar) Batam, Pebrialin di Batam.
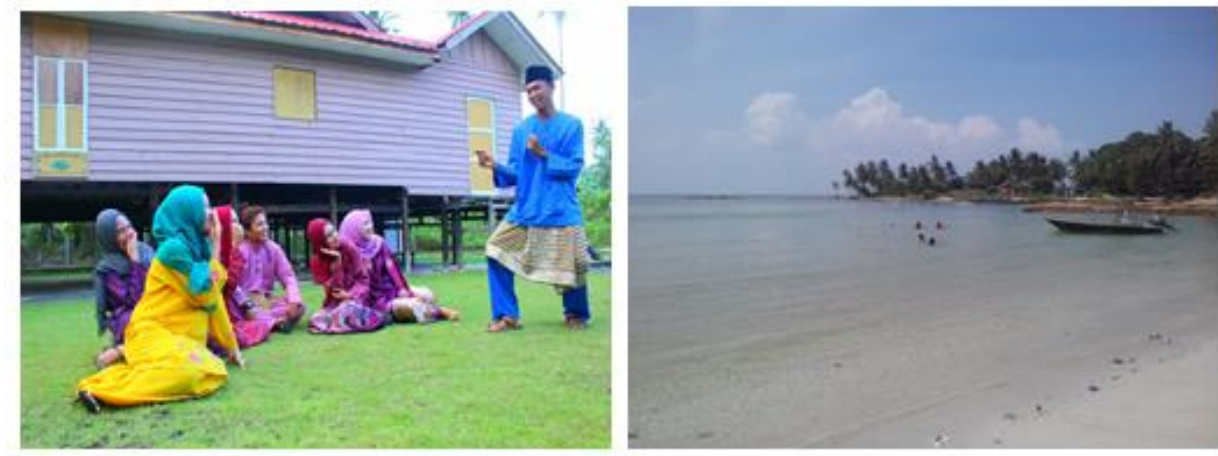

Gambar 1 Keindahan alam kampung tua Nongsa dan kearifan lokal budaya Melayu 
Salah satu komunitas yang sangat peduli tentang keberadaan kampung tua adalah Komunitas Capung (Community Anak Kampung) yang berada di Kampung Tua Nongsa Batu Besar. Komunitas ini berdiri sejak tahun 2014 yang beranggotakan warga muda tempatan. Kegiatan komunitas Capung tidak hanya bergerak dalam kegiatan sosial seperti membantu menyalurkan bantuan ke tempat bencana alam, kegiatan gotong-royong, acara tujuhbelasan, bazaar ramadhan tetapi juga kegiatan yang menjadi agenda penting pada peningkatan perbaikan perekenomian warga setempat yaitu melalui promosi wisata kampung tua dan hasil kerajinan tangan warga melalui kegiatan ekspo kebudayaan. Kegiatan ekspo yang pernah dilaksanakan oleh komunitas Capung dan masyarakat bersama Pemko Batam masih berskala lokal.

Dari hasil wawancara dan observasi yang dilakukan oleh tim pengabdi, ketua komunitas Capung Bapak Agustiawan di kediamannya di Kampung Melayu Batu Besar Nongsa, menceritakan tentang kegiatan yang sudah dilaksanakan dan kegiatan yang akan menjadi wacana kegiatan komunitas ini sambil menunjukkan proposal kegiatan promosi wisata kampung tua yang berjudul Heritage Culture of Kampung Tua Nongsa. Kegiatan yang rencananya diadakan pada tahun 2019 menganggarkan dana sebesar satu milliar rupiah. Perhelatan akbar yang akan mengundang beberapa negara tetangga seperti Singapura, Malaysia, Brunei Darussalam, Thailand, Jepang dan Korea Selatan memperkenalkan kearifan lokal kampung tua sebagai ciri khas budaya Melayu di Pulau Batam, pagelaran budaya, memperkenalkan wisata bahari, wisata mangrove, hasil kerajinan tangan, dan memperkenalkan aneka kuliner Melayu Batam. Komunitas Capung akan bekerjasama dengan pihak swasta dan pemerintah dan masyarakat setempat tentunya. Pelayanan yang ramah dengan kearifan budaya lokal berstandar internasional akan menjadi prioritas bagi semua warga lokal dan tentunya komunitas Capung sebagai pihak penyelenggara.
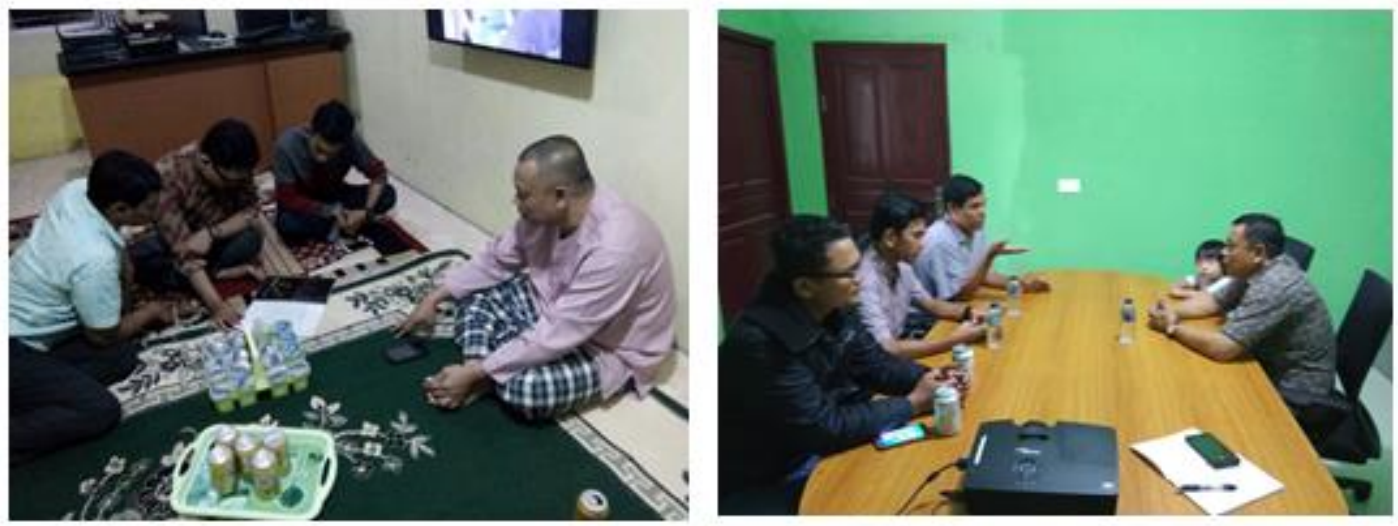

Gambar 2 Wawancara dan observasi kepada ketua komunitas Capung Bapak Agustiawan

Komunikasi adalah kunci dari suksesnya acara ini seperti dikatakan ketua komunitas Capung. Di samping bahasa Indonesia atau Melayu, bahasa Inggris sebagai bahasa global akan dijadikan bahasa sehari-hari dalam melayani pengunjung dari luar negeri. Penggunaan bahasa Inggris yang benar dan sopan akan menjadi salah satu senjata untuk menarik perhatian pengunjung sehingga pengunjung akan betah untuk berlama-lama di Pulau Batam. "Hampir semua anggota komunitas Capung pasif berbahasa Inggris", lanjut Pak Agustiawan ketika ditanya mengenai kemampuan berbahasa Inggris anggota komunitas Capung. Bahasa Inggris bukan bahasa seharihari yang digunakan oleh warga Pulau Batam maka sah saja jika mereka tidak bisa berbahasa Inggris tetapi mereka tidak buta dengan bahasa Inggris karena bahasa Inggris adalah pelajaran wajib dalam kurikulum di SMP dan SMA. Kendala lain dari orang dewasa tidak mau berbahasa Inggris adalah karena tidak percaya diri, malu, takut salah, dan kurangnya kosakata bahasa Inggris [6]. Di samping kendala berbahasa Inggris, ketua komunitas Capung juga mengalami kendala mempromosikan wisata kampung tua berbahasa Inggris berbasis online. Mereka berharap dapat mempromosikan kampung tua dengan eye-catchy, exclusive-art-class dan disampaikan dengan bahasa Inggris sehingga kearifan lokal budaya Melayu sebagai icon wisata kampung tua lebih mendunia.

Anggota komunitas capung adalah pekerja. Mereka bekerja setiap hari dari pagi hingga sore. Rutinitas sehari-hari yang melelahkan membuat mereka berisitirahat saat selesai bekerja. 
Belajar merupakan hal yang melelahkan untuk mereka. Ini menjadi kendala bagi mereka untuk belajar menambah ketrampilan diri seperti ketrampilan berbahasa. Begitu juga jika belajar dengan mengeluarkan biaya, mereka akan mengatakan tidak, sementara ketrampilan berbahasa sangat dibutuhkan dalam pelaksanaan kegiatan ekspo wisata kampung tua yang menonjolkan kearifan lokal budaya Melayu Batam mendatang.
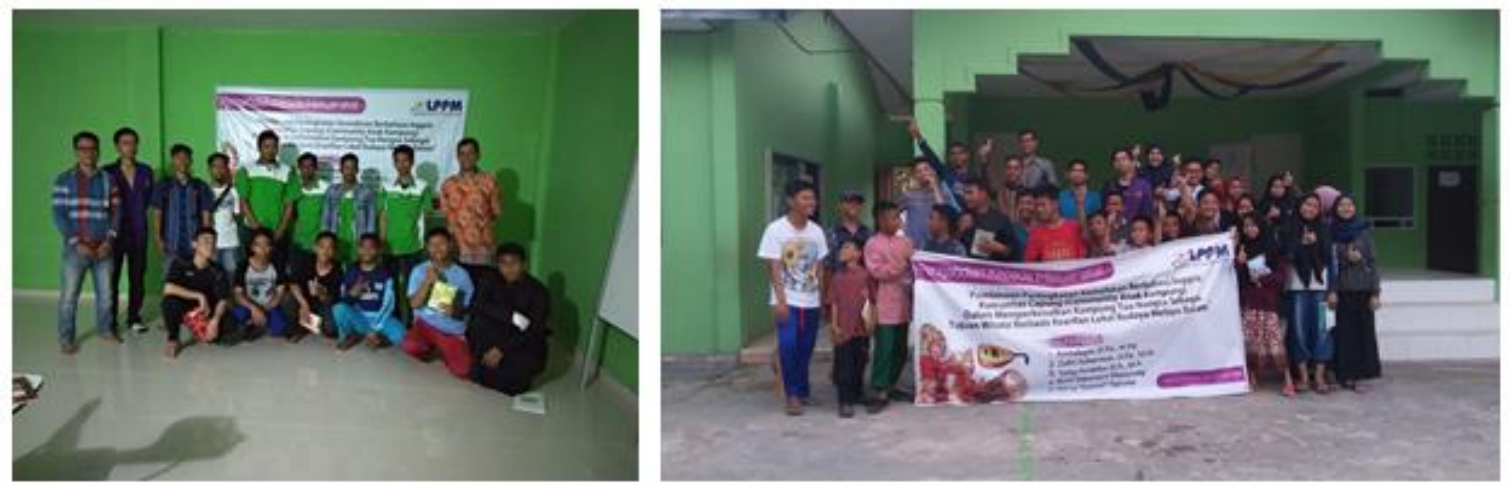

Gambar 3 Anggota Capung dan warga panti asuhan kampung tua Nongsa

Tim pengabdi bersama dengan ketua komunitas Capung kampung tua Nongsa melaksanakan kegiatan pembinaan bahasa Inggris yang mencakup komunikasi, promosi berbahasa Inggris wisata kampung tua pada media sosial online, dan memanfaatkan media sosial dalam mempromosikan wisata kampung tua Nongsa berbasis kearifan lokal.

Keraf mengatakan, 'Jika berbicara mengenai kearifan lokal maka tidak bisa lepas dari budaya dan nilai-nilai yang melingkupinya" [7]. Oleh sebab itu, dengan penggunaan bahasa Inggris dalam mempromosikan wisata kampung tua, kesempatan untuk merperkenalkan kearifan lokal budaya Melayu Indonesia lebih mendunia. Kachru, ahli bahasa dari India mengatakan bahwasanya mengetahui bahasa Inggris seperti sebuah gerbang menuju bisnis international, teknologi, pengetahuan, dan perjalanan [8].
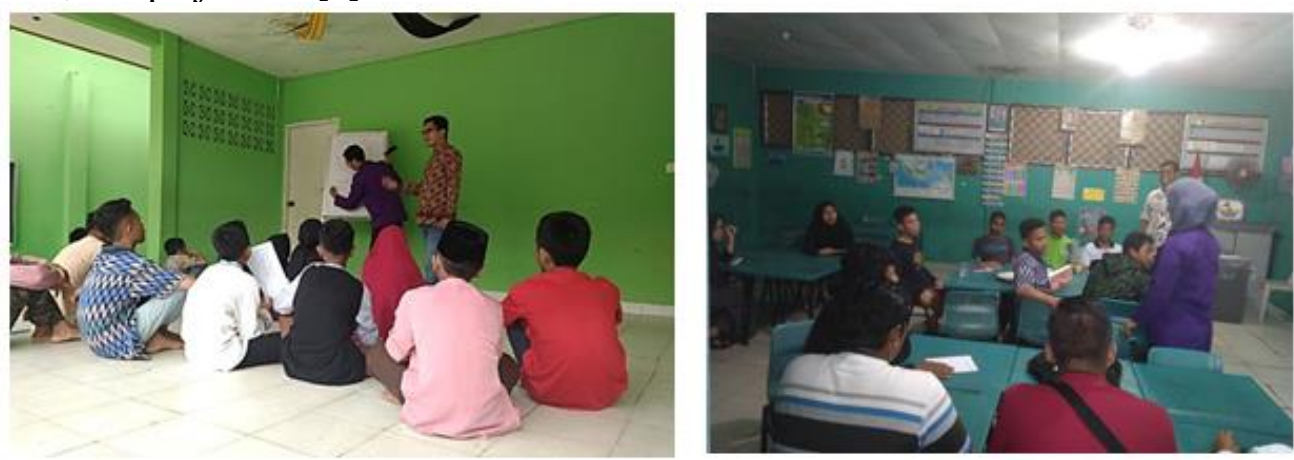

Gambar 4 Kegiatan pengabdian anggota kamunitas Capung dan warga panti asuhan kampung tua Nongsa

Kegiatan pengabdian kepada masyarakat yang dilaksanakan di Kampung Tua Nongsa Batu Besar sangat bermanfaat bagi komunitas Capung. Pembinaan pelatihan bahasa Inggris bertujuan memberikan ketrampilan anggota komunitas Capung berbahasa Inggris lisan dan tulisan sehingga tujuan komunitas Capung dalam mempromosikan wisata Kampung Tua Nongsa berbasis kearifan lokal kepada wisatawan asing terlaksana. Pelatihan pemanfaatan media sosial sebagai media promosi yang efektif dan murah bermanfaat bagi komunitas Capung untuk memperkenalkan Kampung Tua Nongsa sebagai tujuan wisata berbasis kearifan lokal budaya Melayu kepada dunia. Di samping itu, pembinaan pelatihan berbahasa Inggris akan sangat membantu anggota komunitas Capung berkomunikasi kepada wisatawan asing atau pengunjung asing pada saat diadakannya ekspo kebudayaan Melayu Heritage Culture Of Kampung Tua Nongsa 2019 di Nongsa.

Setelah dilakukan wawancara dan observasi, permasalahan yang dihadapi oleh pemuda dan remaja warga Nongsa Batam khususnya anggota komunitas Capung yaitu kemampuan pasif berbahasa Inggris sehingga mereka tidak mampu berkomunikasi dan menjelaskan budaya Melayu 
sebagai suatu kearifan lokal kampung tua di Pulau Batam baik lisan maupun tulisan dalam bahasa Inggris, dan terkendala saat mempromosikan wisata kampung tua berbasis kearifan budaya lokal secara online mengggunakan bahasa Inggris. Dengan kecanggihan teknologi saat ini, memudahkan manusia untuk menjelajah ke seluruh dunia. Memperkenalkan kearifan lokal budaya daerah dengan penjelasan berbahasa Inggris akan memiliki manfaat yang besar untuk mengenalkan kearifan lokal kepada dunia luar. Pemuda sebagai generasi penerus harus mengenal kearifan lokal budaya dimana mereka berada.
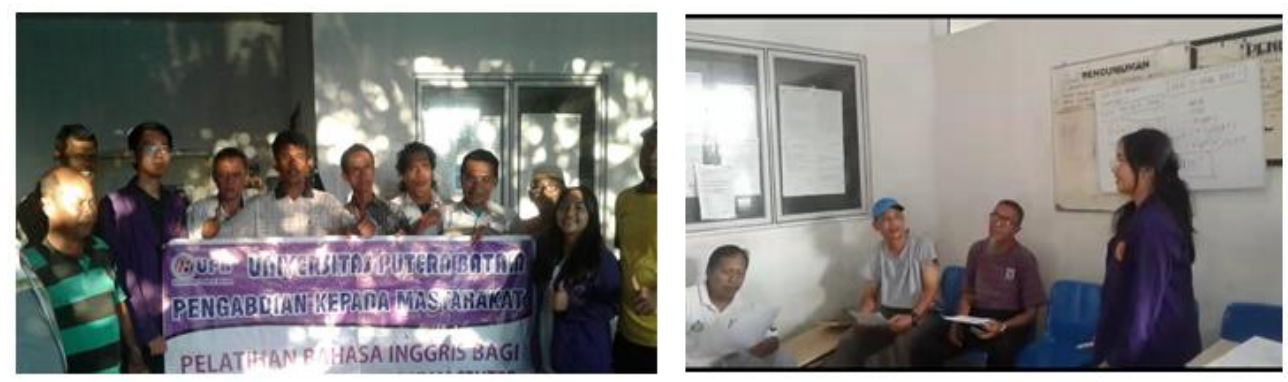

Gambar 5 Kegiatan pengabdian pada supir taksi Pelabuhan Internasional Batam Center

Sebelumnya tim pengabdi juga telah melakukan pengabdian pelatihan bahasa Inggris kepada supir taksi di pelabuhan internasional Batam di tahun 2017 [9] dan pembinaan lanjutan bagi supir taksi [10], dan kepada pegawai perkebunan dan kafe buah naga berbasis agrowisata di Batam di tahun 2018 [11]. Tujuan dari pengabdian ini adalah untuk mengenalkan kearifan lokal Pulau Batam kepada wisatawan asing. Sasaran supir taksi karena supir taksi sebagai garda terdepan pelayanan kepada wisatawan mancanegara.

Dan sasaran pegawai perkebunan dan kafe buah naga karena buah naga adalah buah endemik Pulau Batam, dan merupakan daya tarik pengunjung yang datang ke Pulau Batam. Wisatawan asing sering berkunjungi ke perkebunan dan kafe buah naga di Rempang dan Galang, Pulau Batam. Hasil dari pengabdian tersebut menunjukkan peserta bisa berbahasa Inggris walaupun tidak fasih tetapi mereka mengetahui dasar-dasar berbahasa Inggris.
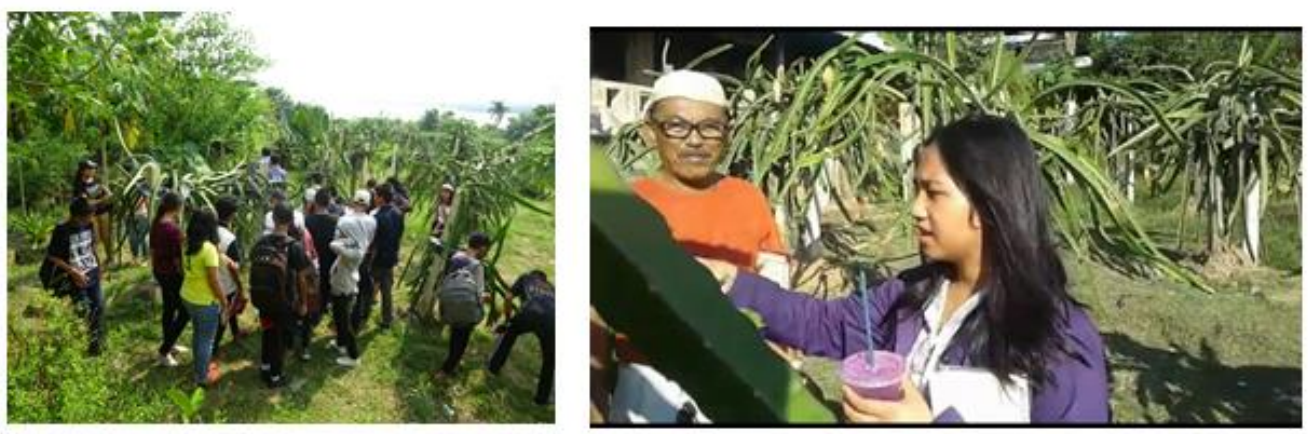

Gambar 6 Kegiatan pengabdian di kebun buah naga Rempang-Galang, Batam

\section{METODE}

Metode yang dilaksanakan dalam menyelesaikan permasalahan oleh tim pengabdi yaitu;

1. Melaksanakan wawancara (in-depth interview) untuk mengetahui kemampuan berbahasa Inggris anggota komunitas Capung sebagai pelajar dewasa (adult learners) yang bekerja.

2. Memberikan pretest kepada anggota komunitas Capung berbentuk tanya-jawab sederhana dalam bahasa Inggris untuk mengetahui kemampuan bahasa Inggris peserta.

3. Melaksanakan pelatihan English Grammar yang di aplikasikan pada writing dan speaking dengan teknik penekanan keaktifan anggota kamunitas Capung (student-center).

4. Melaksanakan pelatihan English Pronunciation untuk memperbaiki pengucapan bahasa Inggris melalui bacaan dan latihan percakapan.

5. Pelatihan storytelling menceritakan tentang kearifan lokal budaya Melayu Batam melalui hikayat, dongeng, sastra, dan kehidupan sehari-hari. Kearifan lokal budaya Melayu dapat disisipkan melalui cerita-cerita rakyat Melayu. 
6. Melaksanakan pelatihan penggunaan media sosial dalam mempromosikan wisata kampung tua sebagai strategi manajemen promosi.

7. Memberikan praktik langsung berbahasa Inggris kepada anggota komunitas Capung baik lisan maupun tulisan (posttest).

8. Memberikan masukan kelebihan dan kekurangan berbahasa Inggris hasil dari posttest (refleksi).

\section{HASIL DAN PEMBAHASAN}

Warga Kampung Tua Batu Besar Nongsa adalah garda terdepan dalam memperkenalkan kebudayaan Melayu kepada tamu-tamu yang datang ke Nongsa di Batam. Tamu-tamu yang berkunjung ke Batam, khususnya wistawan asing akan merasa betah dan ingin datang kembali apabila dilayani dengan baik dari awal sampai akhir dengan menunjukkan keramah-tamahan sebagai kearifan lokal budaya Melayu di Batam. Sebagai negeri Melayu, mengedepankan kearifan lokal budaya Melayu sangatlah penting sebagai daya tarik kepada wisatawan. Terlebih lagi kebanyakan wisatawan berasal dari Singapura dan Malaysia yang sangat mengenal kebudayaan Melayu dan ingin mengetahuinya.

Kesinambungan usaha wisata di Kota Batam tidak lepas dari jumlah wisatawan yang berkunjung. Semakin banyak wisatawan yang datang akan semakin memajukan usaha wisata dan usaha bisnis lain di sekitar sebagai imbasnya. Oleh sebab itu penduduk lokal harus menjaga setiap tutur kata dan perbuatan sehingga tidak menyinggung perasaan tamu-tamu yang datang ke Kota Batam.

Generasi muda yang tergabung dalam komunitas Capung di Kampung Tua Batu Besar Nongsa menyadari bahasa sebagai alat komunikasi sangatlah penting dalam kelancaran kegiatan kepariwisataan. Komunitas Capung sangat peduli dalam memperkenalkan daerah mereka kepada pendatang dari luar negara sehingga berkomunikasi dalam bahasa Inggris sangatlah penting. Latar belakang kemampuan bahasa Inggris pegawai yang rendah menjadi kendala dalam memberikan pelatihan. Oleh sebab itu tim pengabdi memberikan pembelajaran bahasa Inggris secara sederhana sesuai kemampuan peserta.

Peserta adalah mereka yang jarang menggunakan bahasa Inggris sehingga ketika diajarkan untuk mengucapkan peserta merasa canggung dan masih malu-malu. Dengan pendekatan yang membuat mereka mau untuk mengucapkan, akhirnya peserta berlatih mengucapkan. Contoh kata yang sering diucapkan adalah: apologize, what can I do.., sorry, excuse me, thank you, dan yang lainnya. Banyak dari peserta yang sulit mengucapkan kata-kata tersebut. Dengan pelatihan mendengar dan pelatihan yang berulang, peserta dapat mengucapkan dengan benar.

Pembelajaran struktur (grammar), banyak peserta yang merasa kesulitan dalam membuat kalimat sesuai dengan waktu, peserta harus mengetahui pembentukan kalimat berstruktur. Kalimat dasar yang diberikan berbentuk positif, negatif, dan tanya. Peserta diberikan pelatihan yaitu penggunaan do, does, dan did. Penggunaan do, does, dan did untuk mendeskripsikan kalimat tanya. Kalimat future, progressive, dan perfect sebagai bentuk kalimat dasar berbahasa Inggris juga diberikan dalam pelatihan. Serta kalimat dengan menggunakan verb be: is, am, dan are alam pelatihan.

Setelah pelatihan beberapa minggu dan diberikan latihan tertulis, diadakan simulasi kedua dan ketiga, hasilnya adalah peserta dapat melakukan percakapan sederhana dengan mahasiswa meskipun belum cukup memuaskan tetapi mereka masih menggunakan bahasa Inggris. Percakapan berupa pertanyaan salam, dan memberikan informasi tentang budaya Melayu di Nongsa. Peserta merasa sangat perlu untuk melaksanakan pelatihan beberapa pertemuan lagi sehingga pelatihan diberikan lebih dari enam kali. Untuk menstimulasi peserta belajar mandiri, mereka diberi materi yang berisi percakapan sederhana seperti greeting, informing, asking and answering questions, asking for clarification, thanking, apologizing, giving direction, offering, suggesting, and persuading. Tujuan dari pelatihan bahasa Inggris juga agar peserta dapat mensukseskan rencana kegiatan komunitas capung Heritage Culture Of Kampung Tua Nongsa yang diundur di tahun 2018 dan rencananya akan dilaksanakan di tahun 2019. 

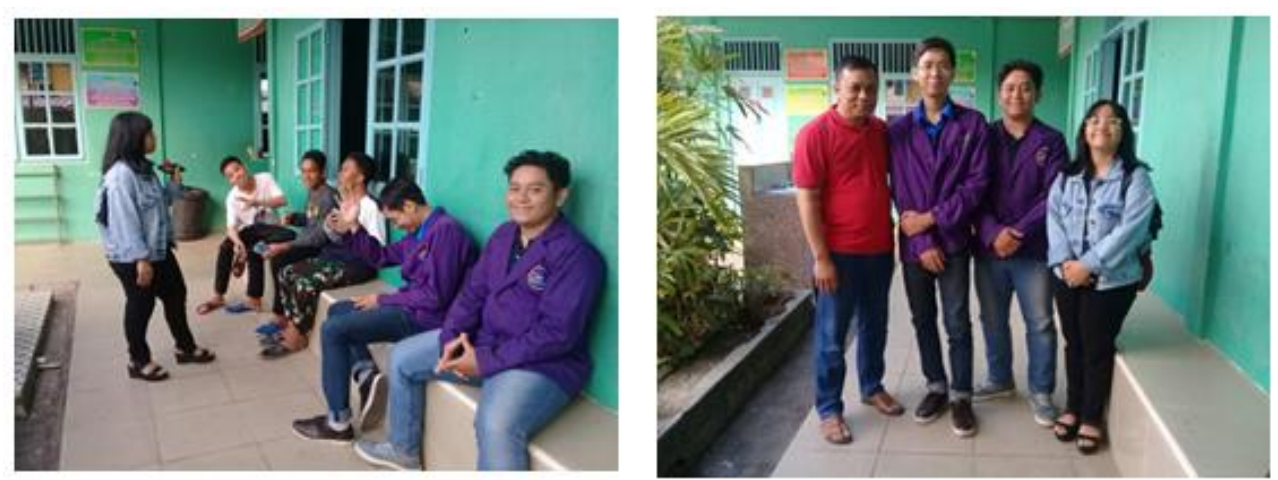

Gambar 7 Tim pengabdi mahasiswa melaksanakan pelatihan percakapan bahasa Inggris kepada peserta

Berkembangnya dunia digital semakin memberikan manfaat yang lebih dalam mempromosikan keindahan dan kearifan budaya Melayu di Batam. Pemberian informasi kepada peserta tentang kebudayaan Melayu kepada dunia menjadi lebih mudah dan cepat. Pengabdian ini memberikan pelatihan mempromosikan kearifan budaya Melayu melalui media sosial seperti instagram. Informasi yang dikemas dengan mennggunakan bahasa Inggris.

Pelatihan penggunaan media sosial dalam memperkenalkan kearifan lokal budaya Melayu di Batam bertujuan untuk menjangkau penyebaran informasi yang lebih mengglobal, efesien, efektif, dan murah. Pelatihan ini lebih mengutamakan penyajian foto dan penyampaian informasi berbahasa Inggris. Tentunya kegiatan ini harus dibarengi dengan fasilitas yang baik. Di samping pemberian informasi secara langsung dari warga setempat kepada pengunjung, pemberian informasi juga dapat dilakukan melalui media digital.

Di zaman yang serba digital, tim pengabdi menyadari bahwa kegiatan ini tidak boleh lepas dari kecanggihan teknologi. Media yang sangat efektif dalam mempromosikan kegiatan kepariwisataan di kampung tua Nongsa berbasis kearifan lokal budaya Melayu harus dikenalkan kepada peserta terlebih peserta adalah mereka yang masih muda. Dari berbagai kalangan dan usia hampir semua masyarakat Indonesia memiliki dan menggunakan media sosial sebagai sarana memperoleh dan menyampaikan informasi ke masyarakat [12].

Tim pengabdi memberikan penjelasan manfaat dari media sosial. Media sosial tidak hanya untuk hal-hal yang bersifat negatif atau mubazir, tetapi lebih dari itu. Media sosial dapat memberikan informasi positif seperti yang akan dilakukan oleh pemuda kampung tua Nongsa dan tim pengabdi dalam mempromosikan kampung tua Nongsa sebagai destinasi pariwisata berbasis kearifan lokal.

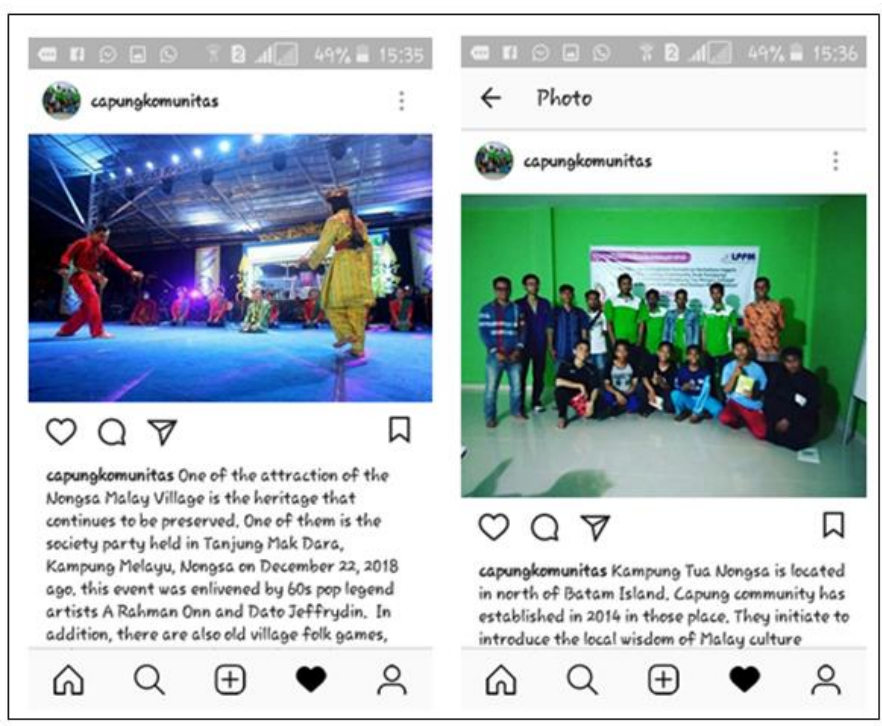

Gambar 8 Promosi kearifan lokal budaya Melayu pada media sosial 


\section{KESIMPULAN}

Untuk mengerti agar pesan tersampaikan tidaklah mudah. Pengaturan kata-kata dalam sebuah kalimat pada ujaran (utterance) haruslah tepat dan jelas. Seperti pada kalimat-kalimat dalam bahasa Inggris, pembentukan kalimat dalam bahasa Inggris haruslah disesuaikan dengan waktu dimana kegiatan dilakukan. Jika pembentukan kalimat tidak sesuai dengan waktu (tense) maka akan mengakibatkan salah dalam mengartikan kalimat tersebut secara semantik ataupun konteks.

Anggota komunitas Capung yang tidak memiliki kemampuan bahasa Inggris, haruslah diberi pembekalan dalam memahami bahasa Inggris lebih dalam sehingga komunikasi yang terjadi berjalan dengan baik dan berdampak positif. Dan wisatawan dapat kembali di kemudian hari. Semakin banyak wisatawan yang berkunjung ke kampung tua akan memajukan perekonomian warga setempat.

Walaupun pelatihan masih dirasa kurang karena pelatihan hanya dilakukan enam kali dalam lima bulan tetapi pelatihan ini merupakan hal yang cukup efektif dalam mengasah kemampuan peserta berbahasa Inggris. Peserta jarang menggunakan bahasa Inggris dalam kegiatan sehari-hari karena aktivitas masing-masing. Tim pengabdi beserta pemuda setempat menyadari akan kendala ini. Rencana lanjutan pelatihan bahasa Inggris akan diwacanakan keberlanjutannya. Hal ini juga disetujui oleh ketua komunitas Capung.

Setelah warga panti asuhan bergabung pada saat pelatihan, ibu-ibu warga sekitar juga berencana mengikuti kegiatan pelatihan bahasa Inggris. Di samping pentingnya bahasa Inggris, ibu-ibu juga berharap dengan mengetahui bahasa Inggris mereka dapat membantu anak-anak belajar di rumah.

Pelatihan dengan durasi waktu yang efektif dan intens cukup ampuh dalam memecahkan masalah peserta berbahasa Inggris. Hal-hal seperti mengajarkan pengucapan, pemberian kosakta, pembentukan kalimat sederhana dalam bentuk positif, negatif, and pertanyaan dan latihan percakapan bahasa Inggris yang mengarah ke topik-topik deskriptif seperti mengungkapkan maaf, mengulangan, penolakan, terima kasih dan lainnya akan sangat membantu para peserta untuk bisa berbahasa Inggris dengan sopan dan baik.

Remaja tidak lepas dari kegiatan di media sosial. Media sosial dapat dimanfaatkan untuk hal yang positif. Dengan semakin canggihnya era digital, informasi akan sangat mudah disebarluaskan. Pemanfaatan media sosial untuk menunjang kegiatan kepariwisataan akan sangat membantu kemajuan perekonomian suatu daerah. Kemasan yang apik bercita rasa internasional dalam mempromosikan kearifan lokal adalah sebuah keahlian yang harus dimiliki dalam memperkenalkan kearifan lokal budaya di Indonesia melalui media sosial. Untuk itu, anggota komunitas diajak untuk mempromosikan kearifan lokal melalui media sosial.

\section{SARAN}

Mengingat akan pentingnya bahasa Inggris dalam memperkenalkan kearifan lokal budaya Melayu di Pulau Batam, perlu diadakan aksi nyata yang mendukung hal ini seperti melaksanakan pelatihan bahasa Inggris yang intens yang dilaksanakan pada kelompok organisasi kepemudaan. Pemuda sekarang begitu dekat dengan dunia digital. Media sosial yang tidak asing bagi pemuda dapat dimanfaatkan dalam mempromosikan budaya suatu daerah sebagai daya tarik sebuah destinasi. Komitmen yang kuat akan memperlancar kegiatan pelatihan yang bertujuan positif untuk kemajuan suatu daerah.

Pemuda sebagai ujung tombak dalam kemajuan suatu daerah akan menjadi guru bagi warga di sekitar. Setelah mendapatkan pelatihan dan ketrampilan, diharapkan keahlian ini dapat diberikan ke warga sekitar sehingga keahlian ini dapat berguna bagi semua pihak.

Pemuda sebagai generasi penerus bangsa ini hendaknya mempunyai cita-cita untuk mengembangkang tanah kelahirannya dengan mengembangkan potensi daerah seperti kearifan lokal daerah masing-masing. Kemajuan teknologi pada saat sekarang ini dapat dimanfaatkan untuk itu. Kearifan budaya lokal dapat diperkenalkan ke dunia dengan bahasa Inggris sebagai bahasa internasional dengan bantuan teknologi komunikasi dan informasi yang berkembang saat ini. 
Diharapkan pengabdian ini akan terus berlanjut karena bahasa Inggris merupakan skill yang pelatihannya dilakukan tidak hanya sekali tetapi harus berkelanjutan. Dan masyarakat harus mendukung kegiatan yang bermanfaat ini untuk masyarakat yang lebih maju dan bermartabat.

\section{UCAPAN TERIMA KASIH}

Tim pengabdi pengucapkan terima kasih kepada Universitas Putera Batam atas dukungannya moril maupun materil sehingga pengabdian kepada masyarakat yang dilaksanakan dengan baik di Kampung Tua Nongsa Batu Besar.

\section{DAFTAR PUSTAKA}

[1] Red/mc, "Kampung Tua Batam menjadi destinasi favorit turis Korsel," Batam, 24-Dec-2017.

[2] A. Dahlan, Sejarah Melayu, Second Edi. Jakarta: PT. Gramedia Jakarta, 2015.

[3] Teamdinamikakeprinews, "Kearifan lokal tetap dijaga dalam pengembangan Batam sebagai kota cerdas," dinamikakeprinews.co, Batam, 28-Apr-2015.

[4] D. Kartikasari, H. A. Oramahi, and M. Idham, "Kearifan lokal masyarakat kelurahan Pasiran dalam pengelolaan hutan kota Gunung Sari kota Singkawang," J. Hutan Lestari, vol. 5, no. 2, pp. 375-381, 2017.

[5] "Asal usul kampung tua Nongsa," 2016. [Online]. Available: http://disbud.kepriprov.go.id/asal-usul-nama-kampung-tua-nongsa/. [Accessed: 01-Jul-2018].

[6] Ambalegin, Suhardianto, and N. Kaprawi, "Obstacles facing learners in speaking English: Non-English teachers' perspective, Putra Batam School," Pertanika J. Soc. Sci. Humanit., vol. 25, no. 1, p. 122, 2017.

[7] A. S. Keraf, Etika lingkungan hidup. Jakarta: Penerbit Buku Kompas, 2010.

[8] Y. Yulia, "An evaluation of English language teaching programs in Indonesian junior high schools in the Yogyakarta province," RMIT University, 2014.

[9] Ambalegin and Suhardianto, "Meningkatkan pendapatan supir taksi pelabuhan internasional Batam Center melalui pelatihan English conversation (pelatihan membuat kalimat bahasa Inggris sederhana)," p. Manuscript submitted for publication, 2017.

[10] Ambalegin, Suyono, F. Wulandari, and R. V. Manurung, "Peningkatan kemahiran informal English conversation supir taksi pelabuhan Internasional Batam Center (pembinaan lanjutan)," p. Manuscript submitted for publication, 2017.

[11] Ambalegin and R. V. Manurung, "Pembinaan peningkatan kemahiran informal English conversation pegawai perkebunan buah naga jembatan empat barelang berbasis agrowisata," p. Manuscript submitted for publication, 2018.

[12] A. S. Cahyono, "Pengaruh media sosial terhadap perubahan sosial masyarakat di Indonesia," Publiciana, J. Ilmu Sos. dan Polit. Fak. Ilmu Sos. dan Polit. Univ. Tulungagung, vol. 9, no. 1, pp. 140-157, 2016. 